Polgári Szemle, 15. évf. 1-3. szám, 2019, 46-64., DOI: 10.24307/psz.2019.0904

Domokos László

\title{
Miként támogatja az Állami Számvevőszék a jó kormányzást a közpénzügyek területén?
}

\section{How Does the State Audit Office of Hungary Support the Good Governance on the Field of Public Finances?}

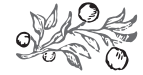

Összefoglalás

Az Állami Számvevôszék (ÁSZ) a jó kormányzást a közpénzek felhasználásának, szabályosságának és eredményességének ellenôrzésével támogatja, amit évente több mint 800 szervezet vizsgálatával ér el, melyek nemcsak a közszféra intézményei és önkormányzatok, hanem köztulajdonú gazdasági társaságok, alapítványok és más nem állami humánszolgáltató szervezetek. További fontos feladata a költségvetés tervezésével és a zárszámadással kapcsolatos kockázatok jelzése, amivel az ország stabilitásához is hozzájárul. Ellenôrzéseken kívül az ÁSZ mintaintézménnyé váló múködésével is elôsegíti a jó kormányzást a közpénzügyek területén.

Journal of Economic Literature (JEL) kódok: E6, F33, H6, H83

Kulcsszavak: Állami Számvevôszék, közpénzügy, költségvetési konszolidáció, államháztartási konszolidáció, átláthatóság, Magyarország Alaptörvénye, Költségvetési Tanács

Summary

The State Audit Office of Hungary (SAO) conducts audit of more than 800 organization, (which can be public institutions, municipalities, state and/or municipality owned

Dомокоs LÁszló PhD, elnök, Állami Számvevôszék (elnok@asz.hu). 
enterprises, foundations and non-state service providers) on the efficiency, effectiveness and the regulation of the usage of public funds in accordance with good governance. In addition, SAO has an important role for analyzing and assessing the budgetary risk and shortcomings, with this action it also supports the stability of Hungary. The SAO not only supports good governance by conducting audit and providing "guide", but also leading by example and functioning as a role model for institutions using public funds.

Journal of Economic Literature (JEL) codes: E6, F33, H6, H83

Keywords: State Audit Office of Hungary, public finance, fiscal consolidation, transparency, Fundamental Law of Hungary, Fiscal Council

\section{BEVEZETÉS}

Egy legfőbb ellenôrző szervezet munkájának hatásossága leginkább azzal mérhetô le, hogy javult-e a közpénzek felhasználásának szabályossága és eredményessége. A nagyobb társadalmi hatás elérése érdekében szükséges lehet az ellenőrzések számának növelése is. Fontosabb ennél, hogy az ellenőrzések a hibák kijavítását, a hiányosságok megszüntetését eredményezzék az ellenőrzött szervezeteknél. Ez azonban csak a közvetlen eredménye a számvevôszéki ellenőrzéseknek. Jelentôsebb lehet a hatás, amit a legfóbb ellenôrzó szervezet jelentései nyilvánosságra hozatalával, céltudatos kommunikációjával, ellenôrzéseire alapozott tanácsadó tevékenysége révén érhet el. Az elmúlt tíz évben az Állami Számvevôszék (ÁSZ) vezetése az ellenôrzések számának növelésére is törekedett annak érdekében, hogy a közpénzek ellenôrzésének ne legyenek fehér foltjai. Elérte azt is, hogy ellenőrzései ne maradjanak következmény nélkül, azaz az ellenôrzött szervezetek tegyék meg az ÁSZ megállapításai és javaslatai alapján szükségessé váló intézkedéseket. Az ÁSZ hasznosulásközpontú, korszerú eszközöket alkalmazó kommunikációs tevékenysége eredményeként növekedett az ÁSZ iránti közbizalom, és a számvevôszéki jelentések, elemzések fontosabb megállapításai, következtetései széles körben ismertté, elismertté váltak.

Az Állami Számvevôszék két olyan jogkörrel rendelkezik, amelyek nem jellemzôek a legfőbb ellenőrzó intézményekre. Az elsô, hogy az ÁSZ nemcsak a költségvetés zárszámadását ellenőrzi, hanem véleményt készít az Országgyúlés részére a költségvetési törvényjavaslat megalapozottságáról is. Az ÁSZ másik különös felhatalmazása ahhoz kapcsolódik, hogy az ÁSZ elnöke hivatalból tagja a Költségvetési Tanácsnak, azaz Magyarország független költségvetési intézményének. Ezzel összefüggésben az ÁSZ törvényi kötelezettsége, hogy elemzéseivel támogassa a Költségvetési Tanács munkáját. E kötelezettség teljesítése érdekében az ÁSZ évente 8-10, a költségvetés helyzetével, a költségvetési politika egyes kérdéseivel foglalkozó elemzést készít. Ebből adódóan az ÁSZ munkájának eredményessége azon keresztül is megítélhetô, hogy mennyire volt képes hozzájárulni a költségvetési egyensúly megteremtéséhez, majd megörzéséhez. 
Domokos László: Miként támogatja az Állami Számvevốszék a jó kormányzást...

A tanulmányban ezért elsôként a Számvevôszéknek a költségvetési stabilizációhoz való hozzájárulását mutatom be, ezt követôen lesz szó arról, hogy az ÁSZ milyen módon járul hozzá a kormányzáshoz a közpénzügyi rendszer egészének területén.

\section{SIKERES KÖLTSÉGVETÉSI KONSZOLIDÁCIÓ A GLOBÁlis PÉNZÜGYI VÁLSÁGOT KÖVETŐEN}

Az ÁSZ munkája a költségvetés területén eredményesnek tekinthetó, mivel 2012 óta a költségvetés egyensúlya helyreállt, és azóta is fennmaradt. A GDP-arányos államadósság pedig folyamatosan mérséklódik. A sikeres konszolidáció jobb megértése végett elôbb célszerú megismerkedni azokkal a körülményekkel, amelyek a konszolidációt szükségessé tették.

A szocialista gazdálkodásból a piacgazdaságba történô átmenet az 1990-es évek elején súlyos gazdasági visszaeséssel járt. Az átállást nehezítette, hogy Magyarország az 1980-as évek végére hatalmas államadósságot halmozott fel. Az 1990-es évek végére azonban a gazdaság növekedési pályára állt, aminek következtében az államháztartás egyensúlyi helyzete is javult, 2002-re az államadósság már alig haladta meg a GDP 50\%át. 2003-tól azonban ismét megbomlott a magyar gazdaság egyensúlya. Ekkor ugyanis a kedvezó világgazdasági helyzet, valamint Magyarország 2004-es európai uniós csatlakozása a külsố források igénybevételét könnyúvé és rövid távon olcsóvá tette. Az akkori magyar kormányzat külsố források bevonásával próbálta a gazdaságot élénkíteni, és különböző, nagyrészt hibás ösztönzốk hatására 2006-tól a külsó, illetve az idegen devizában történô eladósodás útját választották a gazdaság többi szereplôi is (1. táblázat).

1. táblázat: A külsô és belsố egyensúly megbomlását jelzó mutató alakulása, 2003-2011 (GDP \%-ában)

\begin{tabular}{l|r|r|r|r|r|r|r|r|r}
\hline Megnevezés & $\mathbf{2 0 0 3}$ & $\mathbf{2 0 0 4}$ & $\mathbf{2 0 0 5}$ & $\mathbf{2 0 0 6}$ & $\mathbf{2 0 0 7}$ & $\mathbf{2 0 0 8}$ & $\mathbf{2 0 0 9}$ & $\mathbf{2 0 1 0}$ & $\mathbf{2 0 1 1}$ \\
\hline $\begin{array}{l}\text { Nettó finanszírozási } \\
\text { igény }\end{array}$ & $-8,3$ & $-9,6$ & $-8,0$ & $-6,7$ & $-6,5$ & $-5,7$ & 0,9 & 2,1 & 3,3 \\
\hline $\begin{array}{l}\text { Kormányzati szektor } \\
\text { egyenlege }\end{array}$ & $-7,1$ & $-6,5$ & $-7,8$ & $-9,3$ & $-5,0$ & $-3,7$ & $-4,5$ & $-4,5$ & $-5,4$ \\
\hline Bruttó külsó adósság & 57,9 & 69,9 & 80,6 & 90,4 & 102,9 & 120,9 & 142,6 & 143,9 & 148,8 \\
\hline Bruttó államadósság & 63,1 & 58,7 & 60,5 & 64,5 & 65,5 & 71,6 & 77,8 & 80,2 & 80,5 \\
\hline
\end{tabular}

Forrás: Saját szerkesztés KSH adatai alapján

A kormányzati szektor egyenlege több mint kétszeresen, 2006-ban több mint háromszorosan meghaladta az uniós szabályok szerint még megengedett 3 százalékos mértéket, és némi javulás csak 2007-tôl következett be. A nettó finanszírozási igény, azaz a külsố források igénybevételének mértéke még ennél is magasabb volt. Ennek következtében a bruttó külsô adósság rendkívül dinamikusan emelkedett, amelyet 2004-tôl kezdve a bruttó államadósság, illetve annak a külsô forrásokból történô finanszírozása is táplált. 2008-ra a bruttó külsô adósság 2003-hoz képest a duplájára nôtt, a 
bruttó államadósság pedig 2008-ban több mint 10 százalékponttal haladta meg a 60 százalékos uniós limitet.

2008 ôszén ebben a helyzetben érte el Magyarországot a globális pénzügyi válság. A magyar kormánynak az Európai Unió és a Nemzetközi Valutalap által dobott mentôövre, azaz gyorshitelre volt szüksége ahhoz, hogy Magyarország ne süllyedjen fizetésképtelenségbe. Az újabb külsố hitelek következtében Magyarország bruttó külsố eladósodottsága rekordméretûvé nôtt, és megközelítette a GDP másfélszeresét. Fájdalmas megszorító intézkedésekkel sikerült elérni, hogy a kormányzati szektor egyenlege 5 százalék alatt maradjon, de ennek ára a GDP 6 százalékot meghaladó csökkenése volt. Ugyanakkor a vállalkozások és a lakosság is visszafogta a kiadásait, amelynek következtében a nettó finanszírozási igény negatívról pozitívra váltott.

A nemzetközi szervezetek által nyújtott segítség ellenére, a 2010-ben megalakult új magyar kormány számára egyértelmú volt, hogy Magyarországnak saját erejéból kell konszolidálnia a költségvetését, és stabilizálni, majd dinamizálni a gazdaságát. A sikeres konszolidáció eredményeként a költségvetési hiány 2012-re a GDP 3 százaléka alá csökkent, és tartósan az alatt maradt (2. táblázat). Így Magyarország 2013-ban kikerült az Európai Unió szigorú költségvetési felügyeletét jelentô ún. túlzottdeficit-eljárás alól.

2. táblázat: A külsố és belsố egyensúly javulását jelzố mutatók alakulása, 2011-2017 (a GDP \%-ában)

\begin{tabular}{l|r|r|r|r|r|r|c}
\hline Megnevezés & $\mathbf{2 0 1 1}$ & $\mathbf{2 0 1 2}$ & $\mathbf{2 0 1 3}$ & $\mathbf{2 0 1 4}$ & $\mathbf{2 0 1 5}$ & $\mathbf{2 0 1 6}$ & $\mathbf{2 0 1 7}$ \\
\hline $\begin{array}{l}\text { Nettó finanszírozási } \\
\text { igény }\end{array}$ & 3,3 & 4,3 & 7,3 & 5,2 & 7,4 & 6,2 & 4,3 \\
\hline $\begin{array}{l}\text { Kormányzati szektor } \\
\text { egyenlege }\end{array}$ & $-5,4$ & $-2,4$ & $-2,6$ & $-2,6$ & $-1,9$ & $-1,6$ & $-2,2$ \\
\hline Bruttó külsó adósság & 148,8 & 129,2 & 117,8 & 117,1 & 108,7 & 97,0 & 84,9 \\
\hline Bruttó államadósság & 80,5 & 78,4 & 77,1 & 76,6 & 76,6 & 75,9 & 73,3 \\
\hline
\end{tabular}

Forrás: Saját szerkesztés a KSH adatai alapján

A 2. táblázat adatai jól mutatják, hogy 2012-ben megkezdôdött a bruttó államadósság folyamatos csökkenése is. A bruttó külsố adósság mérséklődése még gyorsabb ütemú volt, mivel az államadósság finanszírozásában egyre nagyobb arányt képviseltek a lakosság megtakarításai. A mutatók kedvezô irányú változásához nagymértékben hozzájárult, hogy 2013-tól kezdve felgyorsult a gazdaság növekedése is, amelynek üteme 2018-ban már megközelítette az 5 százalékot.

\section{Az Állami Számvevôszéknek az Államháztartás KONSZOLIDÁCIÓJÁT ELÔSEGÍTÓ ELLENÔRZÉSEI}

2010-ben a magyar államháztartás olyan tartályhoz hasonlított, amelyból több nagy lyukon keresztül folyik ki a víz. Ebben a helyzetben a legfontosabb az volt, hogy ellenőrzéseinket a leginkább kritikus helyekre koncentráljuk, feltárva a hiány keletke- 
Domokos László: Miként támogatja az Állami Számvevốszék a jó kormányzást...

zésének okait, javaslatot téve azok megszüntetésére. E tevékenységek legfontosabb elemei a kötelezô magánnyugdíjpénztárakkal, az önkormányzatok eladósodásával, az államadósság kezelésével, a köztulajdonú gazdasági társaságokkal, a monetáris politika költségvetési kockázataival kapcsolatos ellenôrzések, elemzések voltak.

\section{A kötelezô magánnyugdíjpénztárakkal kapcsolatos ellenörzés}

A legkirívóbb példát a kötelezó magánnyugdíjpénztárak szolgáltatták. Ezt a témakört az Állami Számvevôszék alaposan körbejárta, amikor 2010-ben ellenôrizte a magánnyugdíjpénztárak garanciaalapjának múködését. Az Alap eredeti célja az volt, hogy az esetleg fizetésképtelenné váló magánnyugdíjpénztárak helyett a nyugdíjszolgáltatást a pénztár kedvezményezettjei számára biztosítsa. Az Alap kiürülése esetén a központi költségvetés állt volna helyt a kötelezettségekért. Az Alap gazdálkodását illetôen találtunk kisebb hiányosságokat, az ellenőrzés legfontosabb megállapítása azonban az volt, hogy rámutatott az egész rendszer fenntarthatatlanságára.

Magyarország 1996-ban egy olyan nyugdíjrendszert hozott létre, amelynek a lényege az volt, hogy a fiatalabb korosztályok kivitték az egyéni nyugdíjjárulékuk nagy részét a magánnyugdíjpénztárukba, a társadalombiztosítás így kiesô bevételét pedig a költségvetésből kellett egyre növekvó összegekkel kiegészíteni ahhoz, hogy a már nyugdíjasok ellátását ki lehessen fizetni. A különbözet - amelyet az Európai Bizottság nem volt hajlandó korrekciós tételként elismerni - évrôl évre egyre jobban növelte az államháztartási hiányt és az államadósságot. Néhány jellemzó adat: a központi költségvetés a Nyugdíjbiztosítási Alap támogatására 1998-ban 28,1 Mrd Ft-ot, 2009-ben 599,1 Mrd Ft-ot fordított, ami több mint hússzoros növekedést jelentett, és 2009-ben már meghaladta a GDP 2 százalékát. A nyugellátások finanszírozásához a központi költségvetés egyre növekvố arányban járult hozzá, míg 1998-ban ez az arány 3,6\%-ot, 2009-ben már 21,1\%-ot tett ki.

A 2008-ban kezdődô pénzügyi válság hatására a magánnyugdíjpénztári megtakarítások átlagosan több mint 21 százalékkal mérséklôdtek, azaz nyilvánvalóvá vált annak a veszélye, hogy a magánnyugdíjpénztárban felhalmozott megtakarítások hozama a megtakarítási idószak alatt nem éri el az infláció mértékét. Erre a veszélyre reagálva az Országgyuulés 2009-ben a vonatkozó törvény módosításával hozamgaranciát vállalt, azaz előírta, hogy ha a megtakarítás reálhozama a nyugdíj megállapításáig negatív, akkor a magánnyugdíjat a megtakarítás és az infláció szorzataként kell megállapítani. A döntés olyan időpontban született, amikor a megelózô tizenegy évben az átlagos infláció közel 6 százalék volt, míg a megtakarítások átlagos nominális hozama alig haladta meg az 1 százalékot. Nem kétséges, hogy végsô soron ennek a garanciának a kifizetéséhez is a központi költségvetésnek kellett volna a fedezetet biztosítania. Ennek ellenére még becslések sem készültek arról, hogy ez a garanciavállalás - amit tényszerúbb lenne kitöltetlen csekknek nevezni - hány ezer milliárd forintos jövóbeni többletkiadást jelenthetett az akkori adófizetôk számára. Ezt a pénzügyileg fenntarthatatlan rendszert meg kellett szüntetni. Ezzel sikerült elzárni azt a csapot, amelyen keresztül a nyugdíjjárulék kifolyt az államilag szervezett társadalombiztosításból, és 
stabilizálódott, sốt több éven keresztül szufficitessé vált a Nyugdíjbiztosítási Alap költségvetése.

Az önkormányzatok eladósodását és annak okait feltáró ellenôrzések

Az önkormányzati alrendszer volt a másik erôsen kritikus terület, ezért azt a Számvevôszék 2011-tôl átfogóan ellenôrizte, kezdve a Fôvárosi Önkormányzattal, folytatva a megyei, majd a megyei jogú városi önkormányzatokkal, majd a reprezentatív mintavétellel kiválasztott 62 városi önkormányzattal. Végül számos, kockázatelemzés alapján kiválasztott, kisebb önkormányzat pénzügyi egyensúlyi helyzetét ellenôriztük. Az 1 . ábra szemlélteti az ellenôrzés átfogó megállapításait.

1. ábra: Az önkormányzati alrendszer kötvény-és hitelállományának alakulása, 2007-2010 $(\mathrm{Mrd} \mathrm{Ft})$

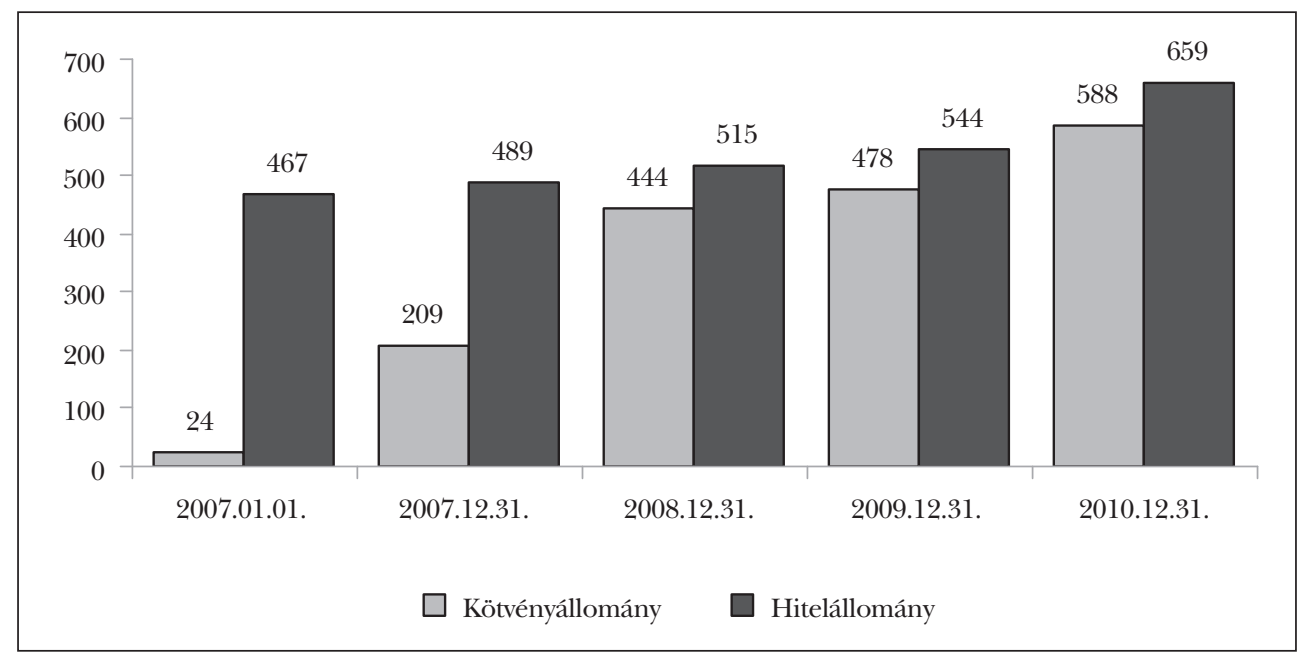

Forrás: ÁSZ, 2012a:12

Az ábrából látszik, hogy az önkormányzati alrendszer kötvénykibocsátásból származó kötelezettsége a 2007. évi nyitóállományhoz képest a 2010. év végére közel 25-szörösére, 588 Mrd Ft-ra emelkedett. A hitelfelvétel miatti kötelezettségek 192 Mrd Fttal, 41\%-kal növekedtek 2010. év végére a 2007. évi nyitó kötelezettségállományhoz képest.

Az ÁSZ 2011 novemberében összegzó jelentést készített az addig elvégzett önkormányzati ellenôrzések tapasztalatairól, és több kormányzati intézkedésre tett javaslatot. Ezek egyfelól a súlyos pénzügyi helyzet megoldását, másfelól az önkormányzatok újbóli eladósodásának megakadályozását célozták. Sor került az önkormányzati adósság konszolidációjára és az önkormányzati adósságot keletkeztetô múveletek kormányzati engedélyhez kötésére. Az önkormányzatok széles körének ellenôrzését az ÁSZ az adósságkonszolidációt követôen is napirenden tartja, mivel 
Domokos László: Miként támogatja az Állami Számvevốszék a jó kormányzást...

a maga eszközeivel meg kívánja előzni egyes önkormányzatok újbóli eladósodását. Az alapos ellenôrzésre éppen azért van szükség, mert a rosszul gazdálkodó önkormányzatok az eladósodás burkolt formáival (pl. a szállítói követelések késedelmes kifizetésével, gazdasági társaságaik hitelfelvételével) tartják fenn ideig-óráig a fizetôképességüket.

\section{Az államadósság-kezelés ellenörzése}

Az államháztartás központi alrendszerének adóssága és éven túli kötelezettségvállalásának ellenőrzésérôl szóló, 2012 augusztusában nyilvánosságra hozott jelentés súlyos hiányosságokat állapított meg (2. ábra).

\section{2. ábra: Az államadósság Ft-deviza összetétel szerinti alakulása}

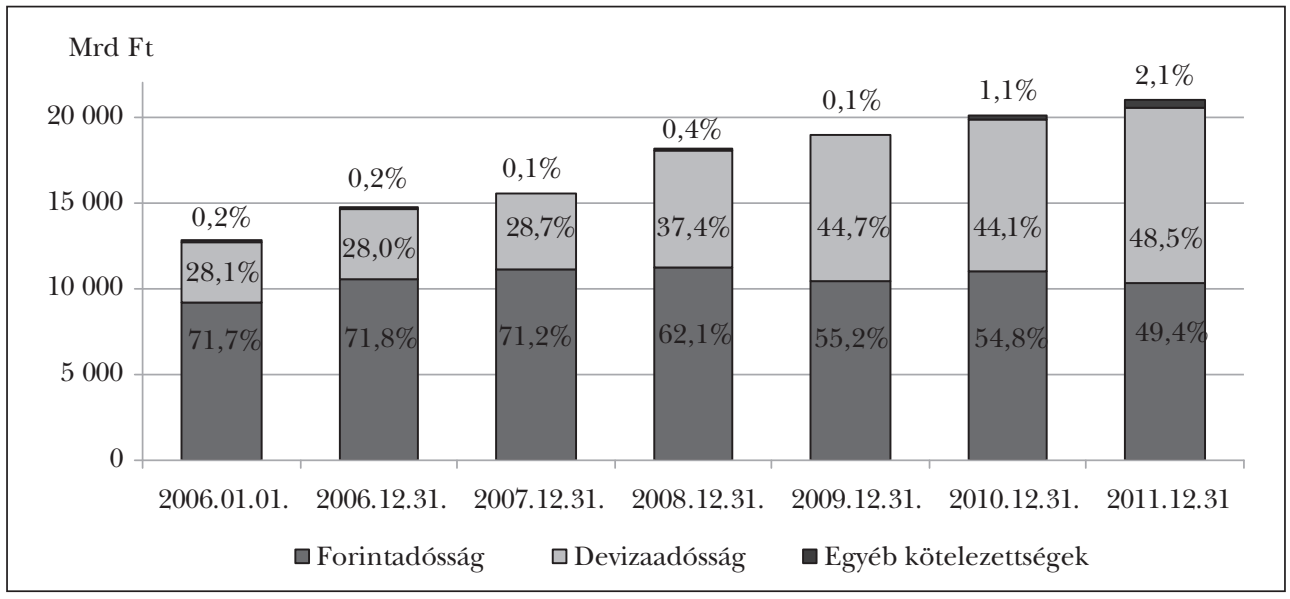

Forrás: ÁSZ, 2012b:17

Az ellenôrzött időszakban lényeges kockázati tényezôt jelentett a devizában fennálló adósság növekedése, a 2006. évi 28,0\%-ról 2009-re 44,7\%-ra. A kockázat 2010ben a forint árfolyamának jelentôs gyengülésével bekövetkezett, és az államadósságot 1656,7 Mrd forinttal növelte meg. Az ÁSZ-ellenőrzés megállapította, hogy az adósságkezelésre 2004-ben kialakított költség- és kockázatkezelési modell belsô fejlesztésére, auditálására és tartalmi felülvizsgálatára nem került sor. A modell nem kezelte a forint- és devizaadósság hátralévố átlagos futamidejét, a hozamgörbe-változás hatását az adósságkezelés költségeire, a piaci stresszhelyzeteket, valamint a hitelminôsítés kockázatát. Az Államadósság-kezelô Központ Zrt. (ÁKK) az egyes pénzügyi és finanszírozási múveletek költségeit és eredményességét nem mérte fel és nem értékelte. Az ÁSZ azt javasolta, hogy a nemzetgazdasági miniszter intézkedjen a kialakított költség- és kockázatkezelési modell felülvizsgálatáról, az adósságkezelési tevékenység költséghatékonyságát alátámasztó értékelési rendszer kialakításáról az adósságfinanszírozási költségeinek nyomon követése, illetve csökkentése érdeké- 
ben. Súlyos jövôbeni terheket azonosítottunk a hosszú távú kötelezettségek ellenôrzése során is (3. ábra).

3. ábra: A hosszú távú kötelezettségvállalások évente tervezett költségvetési kiadásainak alakulása

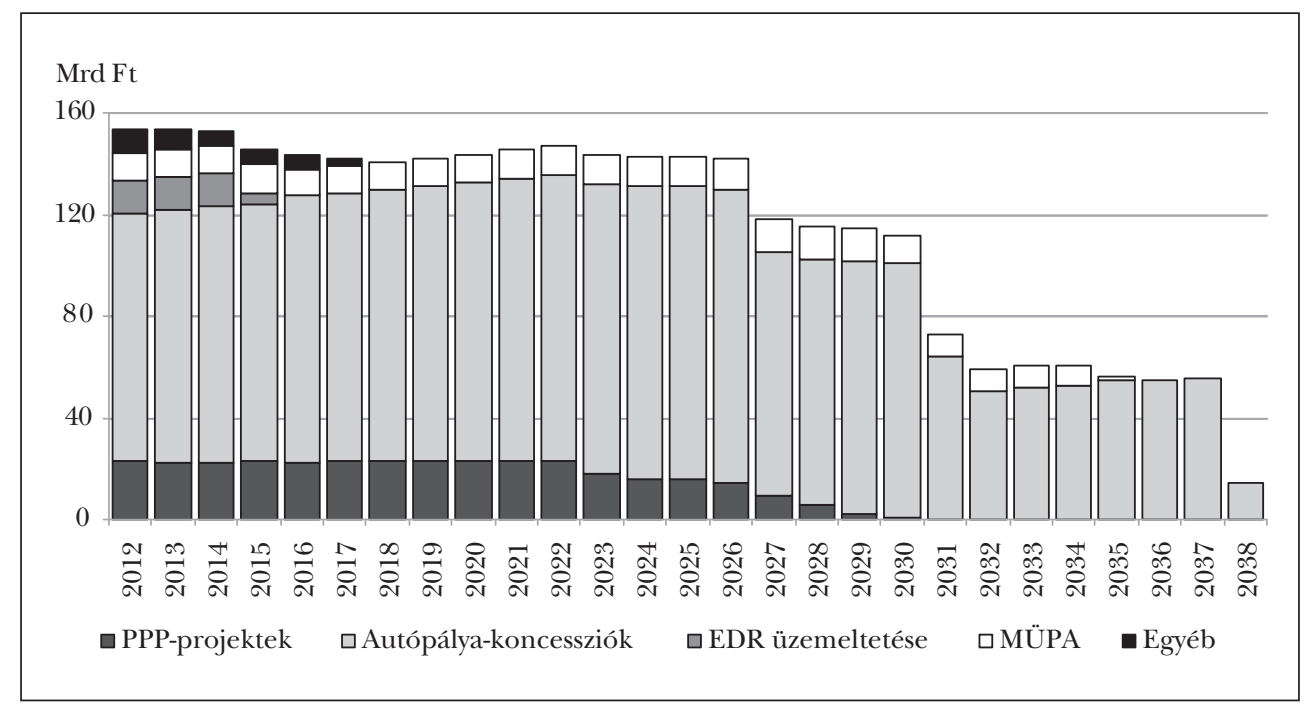

Forrás: ÁSZ, 2012b:25

Az autópálya-koncessziók és a PPP-projektek következtében a magyar költségvetésnek 2027-ig évi 150 Mrd forintos fizetési kötelezettsége keletkezett, és még 2030-ban is meghaladja a kötelezettség összege a 100 Mrd forintot. Ezért az ÁSZ a PPP-konstrukciókban végzett projektek megvalósítását több ellenôrzés keretében vizsgálta. Megállapította, hogy a projektek általában túlárazottak voltak, és a PPP-konstrukciótól elvárható kockázatmegosztás helyett a kockázatokat továbbra is az állami fél viselte. Ezért az ÁSZ kezdeményezte a PPP-szerződések felülvizsgálatát és a feleloosség megállapítását.

Az ÁSZ az államadósság-kezelést minden évben ellenôrizte a zárszámadási ellenôrzés keretében, majd 2015-ben ismét átfogó ellenôrzést végzett. Megállapítottuk, hogy az államadósság árfolyamkockázata az elmúlt években jelentősen mérséklődött azáltal, hogy a devizaadósság részaránya a teljes államadósságon belül 2011. év végi 40\%ról 20\%-ra csökkent (4. ábra).

A devizában történô eladósodás nemcsak az önkormányzatokat és a központi költségvetést, hanem a lakosság széles rétegeit is érintette. A megsegítésükre hozott intézkedések százmilliárdos nagyságrendú kiadást, illetve bevételelmaradást jelentett a központi költségvetés számára. Az intézkedések megvalósulását az ÁSZ a költségvetési zárszámadás ellenôrzése keretében vizsgálta. Külön ellenôrzést az ÁSZ a Nemzeti Eszközkezelő Zrt. 2011 és 2014 közötti vagyonmegőrzési és gazdálkodási tevékenységét érintôen végzett, amelyet szabályosnak ítélt meg. Ez az eszköz segíteni tudta a legsúlyosabb adósságcsapdába esett családok lakhatását. 
Domokos László: Miként támogatja az Állami Számvevốszék a jó kormányzást...

4. ábra: A devizaadósság aránya a bruttó államadósság százalékában

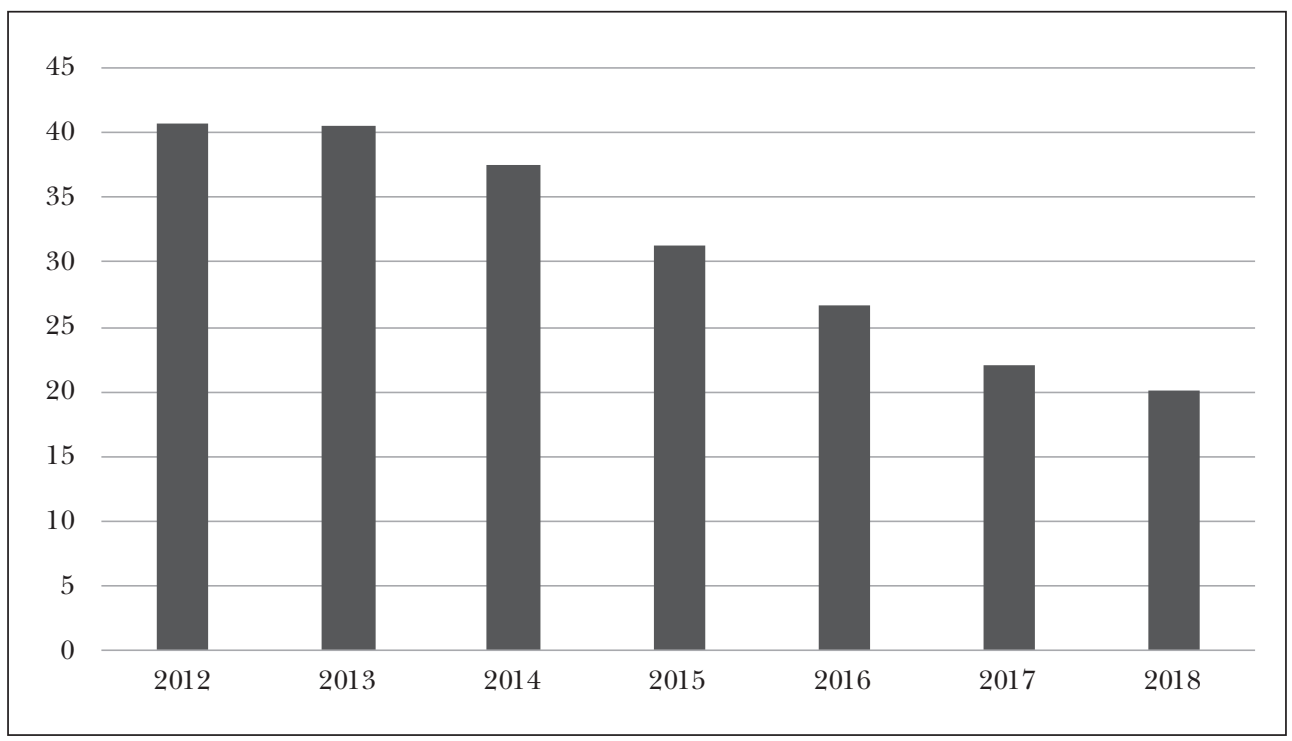

Forrás: Saját szerkesztés az ÁKK Zrt. adatai alapján

A monetáris politika költségvetési kockázatainak elemzése

A devizában történó eladósodás következményeként a kereskedelmi bankok forintban mért likviditása jelentôsen megnótt, amit nagymértékben a Magyar Nemzeti Banknál helyeztek el, amelyek után az MNB magas kamatot fizetett. Az ÁSZ a monetáris politikát nem ellenőrizheti, ezért egy elemzés (Pulay et al., 2013) keretében hívta fel a figyelmet az akkori monetáris politika költségvetési kockázataira. Ebben az elemzésben bemutattuk a kamatterhek dinamikus növekedését (3. táblázat). Az elemzés felvetette olyan szabályozási változások szükségességét, amelyek a Magyar Nemzeti Bank által fizetendô kamatokat mérséklik, és egyúttal a likvid pénzek egy részét átcsatornázzák az államadósság finanszírozására. 2013-tól a jegybank új vezetése megtalálta az általunk javasolt irányba vezetô monetáris politikai intézkedéseket.

3. táblázat: A monetáris eszközök után az MNB által kifizetett összegek (2007-2011)

\begin{tabular}{l|c|c|c|c|c|c}
\hline \multirow{2}{*}{ Monetáris eszköz neve } & \multicolumn{5}{|c}{ MNB által kifizetett (nettó) kamat (Mrd Ft) } \\
\cline { 2 - 7 } & $\mathbf{2 0 0 7}$ & $\mathbf{2 0 0 8}$ & $\mathbf{2 0 0 9}$ & $\mathbf{2 0 1 0}$ & $\mathbf{2 0 1 1}$ & $\begin{array}{c}\mathbf{5} \text { év ösz- } \\
\text { Szesen }\end{array}$ \\
\hline Kötelezó tartalék & 49,6 & 60,9 & 29,4 & 20,0 & 54,6 & 214,5 \\
\hline Kéthetes kötvény & 75,1 & 71,4 & 226,7 & 213,8 & 255,2 & 842,2 \\
\hline Egynapos betét & 0,5 & 12,1 & 24,8 & 4,8 & 8,2 & 50,4 \\
\hline Összesen & 125,2 & 144,4 & 280,9 & 238,6 & 318,0 & 1107,1 \\
\hline
\end{tabular}

Forrás: Saját szerkesztés az MNB adatai alapján 


\section{A kormányzati szektorba sorolt egyéb szervezetek ellenörzése}

Az ÁSZ egyre több állami és önkormányzati tulajdonú gazdasági társaságot ellenôriz, mivel ezek egy része az uniós szabályok szerint a kormányzati szektorba sorolandó, amelynek következtében adósságuk növeli az államadósságot. A kormányzati szektorba sorolt egyéb (azaz az államháztartáshoz nem tartozó) szervezetek esetében növekvô számokról beszélhetünk, mivel egyre több szervezet esetében állapítják meg, hogy gazdálkodásuk jellemzói alapján ide sorolandók. A számuk emelkedésével párhuzamosan növekszik az adósságállományuk is, amelyhez hozzájárul egyes gazdasági társaságok adósságának emelkedése is (4. táblázat).

4. táblázat: A kormányzati szektorba sorolt egyéb szervezetek adósságának alakulása (2010-2016)

\begin{tabular}{l|c|c|c|c|c|c|c}
\hline $\mathbf{E} \mathbf{v}$ & $\mathbf{2 0 1 0}$ & $\mathbf{2 0 1 1}$ & $\mathbf{2 0 1 2}$ & $\mathbf{2 0 1 3}$ & $\mathbf{2 0 1 4}$ & $\mathbf{2 0 1 5}$ & $\mathbf{2 0 1 6}$ \\
\hline $\begin{array}{l}\text { Adósság összesen } \\
\text { (Mrd Ft) }\end{array}$ & 70,3 & 62,5 & 123,5 & 154,9 & 190 & 319 & 332,6 \\
\hline
\end{tabular}

Forrás: Saját szerkesztés az NGM adatai alapján

A táblázat számai jól mutatják, hogy nem jelentéktelen összegról van szó, hiszen az együttes adósságállomány 2016-ban már meghaladta a GDP 1 százalékát. Az ÁSZ nyomon követi ezt a folyamatot, és a kormányzati szektorba sorolt egyéb ellenôrzései során kiemelten vizsgálja, volt-e az ellenőrzött gazdasági társaságnak államadósságot keletkeztetô ügylete, és ennek engedélyezése szabályszerúen történt-e. Ideje volt ezt a kérdéskört ellenórizni, mivel e téren is találtunk súlyos hiányosságokat. Akadt olyan gazdasági társaság, amely nem is tudott arról, hogy a kormányzati szektorba sorolták. Mások azzal nem voltak tisztában, hogy ez komoly következményekkel jár, például a kölcsönök engedélyeztetésének, az adatszolgáltatások vagy a szigorúbb belsố kontrollrendszer kiépítésének kötelezettségével.

A gazdasági társaságok ellenôrzésénél egy másik fontos szempont volt annak ellenórzése, hogy a rezsicsökkentés jelentette kihívásra a közszolgáltató társaságok hogyan tudnak reagálni. Számos esetben azt állapítottuk meg, hogy a közfeladatok és az egyéb feladatok számviteli elkülönítése nem történt meg, a közszolgáltatások díja nincs önköltségszámítással megalapozva, a gazdálkodás hiányossága és a vagyongazdálkodás szabályozatlansága veszteségforrást jelent. Következésképpen a pontosabb elszámolásban, a hatékonyabb gazdálkodásban még jelentősek a tartalékok. A gazdálkodásban és a múködésben számos olyan kockázatot azonosítottunk, amelyek visszavezethetôk voltak a társasági menedzsment, illetve a tulajdonosi joggyakorlás szabályozásbeli hiányosságaira. A köztulajdonú gazdasági társaságok körében végzett ellenôrzéseink erôsítettek meg abban, hogy szükség van az állammenedzsment megújítására. Erre vonatkozó javaslatainkat a kormány elfogadta, és több ponton beépítette a vonatkozó jogszabályokba. 
Domokos László: Miként támogatja az Állami Számvevốszék a jó kormányzást...

\section{A költségvetési törvényjavaslat megalapozottságának véleményezése}

Az Állami Számvevốszék a költségvetési elôirányzatok megalapozottságának véleményezésére egy szilárd alapokon álló módszertant alakított ki és hozott nyilvánosságra. Az ÁSZ a módszertan segítségével számszerúsíteni tudja a tervezett elôirányzatok alul- vagy felülteljesülésének kockázatát, és az így összegzett kockázatot veti össze a költségvetés tervezett tartalékaival. Ha ezek fedezetet nyújtanak a reálisan felmerüló kockázatok kezelésére, akkor nem tartja problematikusnak az adósságszabály teljesülését, ha pedig a tartalékok nem elégségesek, akkor azok megemelését kezdeményezi. Ez azért lényeges, mert ily módon a költségvetési törvényjavaslat véleményezésének középpontjába a tartalékolás kérdésköre került. A megfelelő tartalékolás képes egyidejúleg biztosítani a költségvetési gazdálkodás kiszámíthatóságát és rugalmasságát. A tartalékok teremtik meg a lehetôségét az évközi szigorító intézkedések (elvonások, zárolások), azaz a költségvetési hadigazdálkodás megszüntetésének.

Az Állami Számvevôszék kezdeményezéseinek legfontosabb eredménye, hogy az elmúlt években a költségvetési tervezésben a tartalékok képzésének többszintú rendszere alakult ki. A nem tervezett kiadásokra fedezetet nyújtó általános tartalék, mai nevén „rendkívüli kormányzati intézkedések elóirányzata” mellett létrejött az Országvédelmi Alap, amely elsôsorban a makrogazdasági kockázatok kezelését szolgálja. Általánossá vált, hogy a költségvetési fejezetek is terveznek tartalékot a fejezeti szintú kockázatok kezelésére. A legnagyobb jelentôségú azonban az ún. implicit tartalékok megjelenése. Magát a kifejezést is elsô ízben az Állami Számvevôszék használta, éppen a Költségvetési Tanács részére készített elemzésében.

Implicit tartalékról a hiány és az adósság tekintetében is beszélhetünk. Hiány esetében az implicit tartalék a költségvetési szabály szerinti mérték és az elóirányzott hiány különbözete. Az uniós szabály szerint a kormányzati szektor hiánya a GDP 3 százalékánál nem lehet nagyobb. Ha tehát a kormányzat 2,4 százalékos hiánycélt határoz meg, akkor 0,6 százalékpont az implicit tartalék. Adósság esetén az államadósság-szabály által megengedett mérték és az adósságmutató elôirányzott mértékének a különbsége az implicit tartalék. 2013-tól kezdve a költségvetési törvényjavaslat mindig a megengedettnél kedvezóbb hiánycélt és adósságmutatót irányzott elő. Következésképpen a törvényjavaslat jelentôs implicit tartalékokat tartalmazott. A tartalékolásnak ez a rendszere 2013-tól kezdődôen tényleg szükségtelenné tette év közbeni kiigazító intézkedések foganatosítását. Ez a költségvetési konszolidáció egyik legnagyobb eredménye, mivel ez teremtette meg a költségvetési szervek tervszerú gazdálkodásának a feltételeit, azt, hogy Magyarország Alaptörvényének elôírása szerint a közpénzeket törvényesen, célszerúen, eredményesen használják fel.

Az adóbevétel stabilizálódása a másik fontos tényezó, ami hozzájárult a költségvetési stabilizációhoz. A költségvetési konszolidációhoz jelentôsen hozzájárult az, hogy a tényleges adóbevételek egyre kevésbé maradtak el a tervezettôl, sôt 2015-ben már jelentôs túlteljesítésre is sor került (5.ábra).

A 2010 és 2013 közötti adóbevételek több százmilliárd forinttal maradtak el az elôirányzattól. A fordulópontot 2014 jelentette, amikor összességében már csekély 
5. ábra: A törvényi elöirányzatok és a tényleges teljesitések közötti eltérés (Mrd Ft)

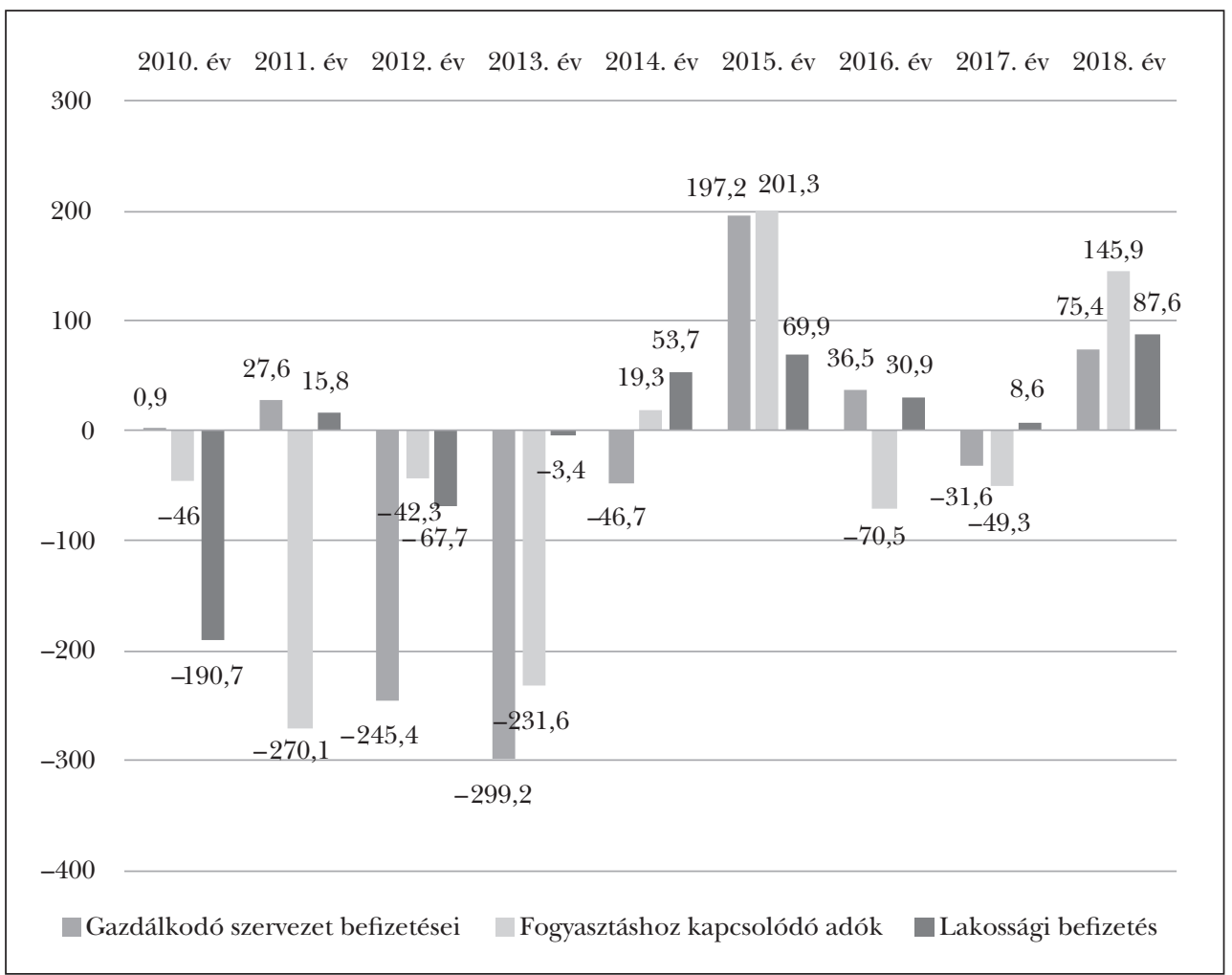

Forrás: Saját szerkesztés NGM-adatszolgáltatás alapján

mértékben túlteljesültek az adóbevételek az elóirányzotthoz képest. 2015-ben pedig már mindhárom adótípus esetében számottevô túlteljesülésre került sor. A 2015. évben befolyt 8 ezer Mrd Ft-ot kitevô adó- és adójellegú bevételek 469 Mrd Ft-tal (6,2\%kal) haladták meg az eredeti elôirányzatot. Jelentős túlteljesülés történt 2018-ban mindhárom típusú adóbevétel esetében.

A gazdaság kifehérítésére és az adóbeszedés hatékonyságának fokozására még további lehetőségek kínálkoznak. Az Állami Számvevôszéknek a Nemzeti Adó- és Vámhivatalnál (NAV) rendszeresen végzett ellenôrzései is feltártak több olyan hiányosságot - pl. az adókedvezmények ellenôrzésénél, a kockázatkezelésben, illetve a hátralékok felhalmozódásának megelôzésében -, amelyek megszüntetése esetén a ténylegesen befolyt adóbevételek jelentôsen növekedhetnek. Az ÁSZ ellenôrzési megállapításai alapján a NAV vezetése számos olyan intézkedést hozott, amelyek hozzájárultak az adóbeszedés hatékonyságának fokozódásához. Az adóbeszedés hatékonyságának fokozása azonban nem öncél, hanem eszköz arra, hogy az adókulcsok csökkenhessenek, és ez által a gazdaság versenyképessége javulhasson. Ezért az ÁSZ szorgalmazta a gazdaság „fenntartható kifehérítését”. Ennek lényege, hogy a gazdaság kifehérítéséból eredő többleteket az állam kisebb adókulcsok vagy célzott kedvezmények formájában 
Domokos László: Miként támogatja az Állami Számvevốszék a jó kormányzást...

az adózóknál hagyja, a kisebb adókulcsok révén pedig tovább fehéredhet a gazdaság. Az utóbbi évek adópolitikai intézkedései ezt a szándékot tükrözik.

\section{TRANSZPARENCIA MAKRO- ÉS MIKROSZINTEN}

Magyarország Alaptörvénye 39. cikk (2) bekezdése általános érvénnyel fogalmazza meg az átláthatóság követelményét, amikor kimondja, hogy a „közpénzekkel gazdálkodó minden szervezet köteles a nyilvánosság elôtt elszámolni a közpénzekre vonatkozó gazdálkodásával. A közpénzeket és a nemzeti vagyont az átláthatóság és a közélet tisztaságának elve szerint kell kezelni. A közpénzekre és a nemzeti vagyonra vonatkozó adatok közérdekú adatok”. A közélet tisztaságának elve a közpénzek rendeltetésszerú, azaz korrupciótól, csalástól mentes felhasználását jelenti.

A pénzügyek, illetve a pénzügyi közvetítôrendszert alkotó intézmények esetében használatos a makroprudenciális és mikroprudenciális felügyelet kifejezés. Magyarországon jelenleg mindkettôt a Magyar Nemzeti Bank látja el. A mikroprudenciális felügyelet feladata a pénzügyi közvetítô intézmények egyedi kockázatai megfelelô kezelésének felügyelete, míg a makroprudenciális felügyelet a pénzügyi rendszer egészét veszélyeztetô rendszerkockázatokat kíséri figyelemmel, és kezdeményez szükség esetén intézkedéseket. A prudens, azaz előrelátó, indokolatlan kockázatvállalástól tartózkodó magatartás és annak felügyelete azért indokolt, mivel pénzügyi közvetítő intézmények nem a maguk, hanem betéteseik pénzét fektetik be, azaz veszteséges gazdálkodásuk vagy likviditási nehézségeik a betéteseiket hozza nehéz helyzetbe.

Hasonlóképpen a közpénzból gazdálkodó szervezetek sem a saját pénzüket költik, hanem azt a pénzt, amit az állam a polgáraitól szed be a közfeladatok ellátásának finanszírozására. Így indokolt, hogy a közpénzt használó intézmények gazdálkodására is szigorúbb szabályok vonatkozzanak, mint azokra, amelyek a saját pénzükból gazdálkodnak. Ahogy a pénzügyi közvetítô intézményekkel szemben az alapvetô feltétel a prudens múködés, úgy a közpénzból gazdálkodó szervezetekkel szemben az alapvetô követelmény az átláthatóság és a korrupciótól való mentesség. Ennek kell makroszinten (a kormányzat szintjén) és mikroszinten (az egyes intézmények szintjén) érvényesülnie. Az Állami Számvevôszék feladata makroszinten és mikroszinten egyaránt ellenôrizni az átláthatóság és a közélet tisztasága követelményének érvényesülését.

A makroszintú ellenőrzés két legfontosabb területe a központi költségvetési törvényjavaslat véleményezése (errôl már bővebben szóltunk), illetve a központi költségvetés végrehajtásáról szóló kormányzati beszámoló, azaz a zárszámadás ellenôrzése. A zárszámadás ellenốrzése minden számvevôszék legfontosabb feladata. Az Állami Számvevôszék elődjét is azért hozták létre 1870-ben, hogy az Osztrák-Magyar Monarchián belül önállóságot élvezô magyar államháztartás költségvetésének zárszámadását ellenôrizze. Jelenleg is ez az a számvevôszéki ellenôrzés, amely a legnagyobb kapacitást igényli. Az ÁSZ számára a szakmai kihívást az jelentette, hogy miként tud a több ezer oldalas beszámoló megbízhatóságáról meggyôződni. Korábban az ÁSZ vezetése azt a megoldást választotta, hogy a nagyobb tételek évenkénti ellenôrzése mellett, minden évben más intézménycsoport beszámolóját ellenôrizte tüzetesebben. 2015. évi zárszá- 
madás ellenôrzésére tudta az ÁSZ azt a módszertant kifejleszteni és alkalmazni, amelynek segítségével a teljes beszámoló megbízhatóságáról képes megalapozott értékelést mondani minden évben.

Mikroszinten a legnagyobb kihívást a közpénzt, közvagyont használó szervezetek nagy száma jelenti. Körülbelül húszezer szervezet tartozik ebbe a körbe, a költségvetési szervektôl kezdve a köztulajdonban álló gazdasági társaságokon át a közfeladatot ellátó nem kormányzati szervezetekig (pl. alapítványi és egyházi intézmények). Ennyi szervezetet az 500 fôs létszámú ÁSZ hagyományos módszerekkel csak évtizedek alatt lenne képes ellenôrizni. Ezért reális célként azt nem lehet kitúzni, hogy az ÁSZ mind a húszezer szervezetet ellenőrizze négy-öt éven belül. Az azonban fontos, hogy minden közpénzból finanszírozott szervezet annak tudatában gazdálkodjon, hogy tevékenységét, elszámolásait az Állami Számvevôszék bármikor ellenôrizheti. E cél elérése megkívánta, hogy az évente ellenôrzött szervezetek száma a 2010 elótti 200 körüliról 800 fölé emelkedjen (5. táblázat), és a közszférában ne legyenek olyan „fehér foltok”, amit soha nem ér el a számvevószéki ellenôrzés. Ez utóbbi célt szolgálta például a nemzetiségi önkormányzatok és a köztestületek (kamarák) ellenôrzése, amelyeket az ÁSZ korábban még nem ellenőrzött, majd a köztulajdonban álló gazdasági társaságok ellenơrzése, amelyek átfogó számvevőszéki ellenőrzésére 2011 után nyílt jogi lehetőség. 2017-tôl kezdve a nem állami fenntartású, de közszolgáltatást nyújtó szervezetek ellenơrzése kezdődött meg széles körben.

5. táblázat: Az Állami Számvevôszék által évente nyilvánosságra hozott ellenôrzési jelentések és az ellenốrzött szervezetek száma (2011-2016)

\begin{tabular}{l|c|c|c|c|c|c|c|c}
\hline & $\mathbf{2 0 1 1}$ & $\mathbf{2 0 1 2}$ & $\mathbf{2 0 1 3}$ & $\mathbf{2 0 1 4}$ & $\mathbf{2 0 1 5}$ & $\mathbf{2 0 1 6}$ & $\mathbf{2 0 1 7}$ & $\mathbf{2 0 1 8}$ \\
\hline Ellenórzési jelentések száma & 71 & 112 & 194 & 233 & 221 & 260 & 251 & 323 \\
\hline Ellenórzött szervezetek száma & 387 & 499 & 569 & 966 & 717 & 740 & 874 & 806 \\
\hline
\end{tabular}

Forrás: Saját szerkesztés az ÁSZ éves beszámolóinak adatai alapján

Az ellenôrzött szervezetek számát 2013-ra sikerült 500 fölé emelni, amihez közel 200-ra kellett emelni az ellenôrzések számát. (Minden ellenôrzésról egy jelentés készül, egy ellenôrzés keretében azonban több szervezet ellenôrzésére is sor kerülhet.) Az utóbbit elsôsorban az ún. témacsoportos ellenôrzések bevezetése tette lehetôvé, mely során a hasonló típusú szervezetek (pl. központi költségvetési szervek, önkormányzati tulajdonú gazdasági társaságok, erdôgazdaságok, múzeumok stb.) tevékenységének egy-két kiemelt területét (pl. belsố kontrollok kiépítettsége és múködtetése, vagyongazdálkodás stb.) az ÁSZ azonos ellenôrzési szakmai program alapján ellenôrzi. Ez nemcsak azért bizonyult hasznosnak, mert így egy szakmai program alapján 10-30 szervezet ellenőrzése is elvégezhetô volt, hanem mert a témacsoportos ellenőrzések feltárták egy-egy terület tipikus hiányosságait is. Következésképpen a nyilvánosságra hozott jelentések a terület azon szervezetei számára is útmutatásul szolgáltak az esetleges hibák kijavításához, amelyek ellenôrzésére nem került sor. E hasznosulási lehetôség jobb kihasználása érdekében számos témacsoportos ellenôrzés tapasztala- 
Domokos László: Miként támogatja az Állami Számvevốszék a jó kormányzást...

tairól az ÁSZ elemzést készített, ezeket nyilvánosságra hozta, sôt több esetben ún. „Jó gyakorlatok" konferenciák keretében ismertette.

Az ellenôrzött szervezetek száma tekintetében a 2014-es esztendó jelentette a csúcsot. A számok mindenáron való növelése nem célunk, hiszen ez adott kapacitás mellett az ellenőrzések minôségét veszélyeztethetné. Ugyanakkor a 2015 és 2018 közötti adatok jelzik, hogy az ÁSZ fenntartható módon képes évente több mint 200 ellenôrzés lefolytatására, ami együtt jár 700-900 szervezet ellenôrzésével. Jelenleg olyan új ellenórzési módszereken dolgozunk, amelyek lehetôvé tennék az ellenőrzött szervezetek számának további növelését. Az elképzelés lényege, hogy az ellenőrzés elsố moduljában a kockázatok feltárását végeznénk el, és további ellenôrzési modulok lefolytatására csak a kockázatosnak bizonyult társaságoknál kerülne sor.

Az Állami Számvevôszékrôl szóló új törvény elfogadását követôen az ellenôrzések fókuszterületeit a belsố kontrollrendszer, a számviteli rend, a vagyongazdálkodás, a pénzügyi helyzet és gazdálkodás ellenôrzése jelentették. E témakörök mind szorosan kapcsolódnak a közszféra szervezetei gazdálkodásának átláthatóbbá tételéhez. Ezzel párhuzamosan azonban a makroszintú átláthatóság javítása is fontos célkitúzés maradt: 2015 óta meghaladja az évi kétszázat azon ellenőrzéseink száma, amelyeknek a fókuszában a jól irányított állam támogatása és a gazdasági versenyképesség fokozása állt.

\section{A JÓL IRÁNYÍTOTT ÁLLAM MỨKÖDÉSÉNEK SEGÍTÉSE A KÖLTSÉGVETÉS TERÜLETÉN}

Az Állami Számvevôszékrôl szóló, 2011-ben elfogadott új törvény egyik leginkább újszerú rendelkezése azt rögzíti, hogy az ÁSZ „az ellenôrzési tapasztalatain alapuló megállapításaival, javaslataival, tanácsaival segíti az Országgyúlést, annak bizottságait és az ellenôrzött szervezetek munkáját, amellyel elôsegíti a jól irányított állam múködését”. Ennek kapcsán elôször arra a kérdésre célszerú választ adni, hogy mi az az irány, amelynek követésében az ÁSZ az állami szerveket segíti. Magyarország Alaptörvényének kihirdetése, azaz 2011. április 25. óta egyértelmú választ lehet adni erre a kérdésre, mivel az Alaptörvény - amelynek Magyarország történetében elôször egy önálló közpénzügyi fejezete is van - a közpénzekkel való gazdálkodásnak határozott irányt szabott. Mindenekeloott az Alaptörvény 36. § (4)-(5) bekezdésében rögzített államadósság-szabályt szükséges kiemelni, melynek értelmében „Az Országgyúlés nem fogadhat el olyan központi költségvetésről szóló törvényt, amelynek eredményeképpen az államadósság meghaladná a teljes hazai össztermék felét. [...] Mindaddig, amíg az államadósság a teljes hazai össztermék felét meghaladja, az Országgyúlés csak olyan központi költségvetésról szóló törvényt fogadhat el, amely az államadósság a teljes hazai össztermékhez viszonyított arányának csökkentését tartalmazza.”

Tekintve, hogy a magyar államadósság még jelentôsen meghaladja a teljes hazai össztermék, azaz a GDP 50 százalékát, jelenleg az adósságmutató (államadósság/ GDP) folyamatos javítása a feladat. Erre tekintettel az ÁSZ ellenôrzései és tanácsadó tevékenysége során is prioritásnak tekinti az államadósság-szabály teljesítésének elôsegítését. Az ellenôrzések esetében ez azt jelenti, hogy az ellenôrzési témakörök kiválasz- 
tásánál elsôbbséget kapnak azok a területek, amelyeknek a gazdálkodása, múködése közvetlenül befolyásolja az államadósság alakulását, és esetükben az ellenôrzés egyik fókuszterülete éppen az államadósságra gyakorolt hatás feltárása, illetve az erre vonatkozó adatszolgáltatás szabályszerúségének, megbízhatóságának megállapítása. Az elemzések témaválasztásánál is nagy súllyal esik latba az államadósságra gyakorolt hatás, de az elemzések az adósságmutató nevezôjére, azaz a GDP alakulásában meghatározó tényezôkre is kiterjednek. Példaként említhetjük a versenyképességet, a kutatás, fejlesztés és innováció ösztönzését, illetve az állam gazdasági szerepvállalását elemzô ÁSZ-tanulmányokat (Pulay et al., 2015; 2016; 2017).

Az Alaptörvény közpénzügyi fejezetének egyéb rendelkezései tovább egyértelmúsítik, hogy mit jelent a jól múködó állam a költségvetés területén. Az Alaptörvény 37. cikk (1) bekezdése rögzíti, hogy a „kormány a központi költségvetést törvényesen és célszerúen, a közpénzek eredményes kezelésével és az átláthatóság biztosításával köteles végrehajtani”. Erre rímel az Alaptörvény 43. cikkének (1) bekezdése, amely az ÁSZ legfőbb feladatait sorolja fel: „Az Állami Számvevőszék törvényben meghatározott feladatkörében ellenőrzi a központi költségvetés végrehajtását, az államháztartás gazdálkodását, az államháztartásból származó források felhasználását és a nemzeti vagyon kezelését. Az Állami Számvevôszék ellenőrzéseit törvényességi, célszerúségi és eredményességi szempontok szerint végzi.” A két idézett alaptörvényi rendelkezés együttállásából az következik, hogy a jól múködó állam a közpénzekkel törvényesen, célszerúen, eredményesen és átlátható módon gazdálkodik, és ennek egyik garanciája éppen az ÁSZ ellenôrzési tevékenysége, amely egyaránt kitérhet a törvényességre, a célszerúségre és az eredményességre, és hozzájárul az átláthatósághoz is azáltal, hogy ellenôrzési jelentései nyilvánosak.

Az ÁSZ az ellenôrzései mellett tanácsadó funkcióját megalapozó elemzéseivel is segíti a jól irányított állam múködését. Ennek jogszabályi alapját az ÁSZ törvény 5. § (13) bekezdése teremtette meg, amelynek értelmében „Az Állami Számvevôszék feladatkörében elemzéseket és tanulmányokat készíthet. Az Állami Számvevôszék az elnök 13. § (2) bekezdés l) pontjában foglalt feladataihoz kapcsolódóan elemzéseket és tanulmányokat készít, ezek rendelkezésre bocsátásával segíti a Költségvetési Tanácsot feladatai ellátásában”. Az ÁSZ elnöke „a Költségvetési Tanács tagjaként ellátja a külön törvényben meghatározott ez irányú feladatait".

A törvényi rendelkezéseknek ez az együttállása rávilágít arra, hogy az ÁSZ rendkívül fontos feladatot és hatáskört kapott a költségvetési kockázatok jelzésére azáltal, hogy elnöke hivatalból tagja a Költségvetési Tanácsnak (a továbbiakban: Tanács). Az elnök tagsága révén ugyanis az egész szervezet kötelezettségévé vált az, hogy olyan elemzéseket és tanulmányokat készítsen, amelyek segítik a Tanácsot feladatai ellátásában. Ezeknek az elemzéseknek az ÁSZ ellenôrzési tapasztalatain kell alapulniuk, de legalábbis kapcsolódniuk kell az ÁSZ feladatköréhez. Túlzás nélkül állíthatjuk, hogy az ÁSZ-törvény hivatkozott rendelkezéseinek végrehajtása érdekében az ÁSZ-nak egy új elemzési múfajt kellett létrehoznia. Ennek két alapvetô jellemzôje az, hogy az ÁSZ ellenôrzési tevékenységéhez kapcsolódnak, a jól irányított állam múködését segítik elô a költségvetés területén. 
Domokos László: Miként támogatja az Állami Számvevốszék a jó kormányzást...

Látni kell azt is, hogy az így megteremtett jog és kötelezettség révén megduplázódtak az ÁSZ lehetôségei a költségvetési kockázatok jelzésére és a hiányosságok kiküszöbölésének indítványozására. Egyfelôl az ÁSZ 1990-es újraalakulása óta minden évben véleményezi az Országgyúlés részére benyújtott költségvetési törvényjavaslatot. Véleményét speciális módszerrel végzett ellenôrzéssel alapozza meg (ÁSZ, 2014). Emellett minden évben ellenôrzi a zárszámadást is. Másfelól az ÁSZ elemzéseivel támogatja a Tanácsnak a költségvetés véleményezésével kapcsolatos munkáját. A Tanács kétszer mond véleményt a költségvetés kidolgozásának és elfogadásának folyamatában. Elôször a költségvetési törvényjavaslat tervezetét véleményezi, tehát azt a változatát, amely már túljutott a tárcák közötti egyeztetésen, de amelyet a kormány még nem nyújtott be az Országgyúlés részére. A Tanácsnak tehát lehetôsége van arra, hogy a tervezett költségvetéssel kapcsolatos kockázatokra felhívja a kormány figyelmét, annak még a végleges döntése elôtt. Másodszor a Tanács a költségvetési törvényjavaslatot annak megszavazása elôtt véleményezi, tehát akkor, amikor abba már beépítették az országgyúlési képviselôk elfogadott módosítási javaslatait.

E véleményezés igen lényeges előrelépés a megelôző szabályozáshoz képest, amely szerint az országgyúlési képviselők javaslataival módosított törvényjavaslatot a kormánytól független szervezet nem véleményezte, így előfordulhatott (és előfordult), hogy az elfogadott törvény lényegesen nagyobb kockázatot tartalmazott, mint a kormány által benyújtott. Például azért, mivel a képviselók a kiadások növelésére fogalmaztak meg jó szándékú javaslatokat, ennek fedezetét azonban a tartalékok csökkentésével vagy a bevételi előirányzatok túlfeszítésével teremtették meg. E veszély kizárása érdekében a Tanács nemcsak véleményezési, hanem vétójogot is kapott: az Országgyúlés csak akkor szavazhatja meg a törvényjavaslatot, ha az teljesíti az ún. adósságszabályt, azaz a várható hiány következtében a kormányzati szektor adóssága kevésbé nő, mint a bruttó nemzeti termék (GDP) folyó áron, következésképpen az államadósság-mutató javul. Ha ez a feltétel nem teljesül, akkor a kormánynak addig kell módosító javaslatokat kezdeményezni és az Országgyúléssel elfogadtatni, ameddig a várható hiány az adósságmutató teljesüléséhez szükséges mértékúre csökken.

További elôrelépés, hogy a Tanácsnak az említett jogkörei nemcsak az eredeti költségvetés elfogadásakor, hanem a költségvetési törvény évközi módosítására vonatkozó törvényjavaslat elfogadásakor is megvannak. A költségvetési törvényjavaslatok különbözô változatainak véleményezése mellett a Tanács félévente véleményt nyilvánít a központi költségvetésrôl szóló törvény végrehajtásának helyzetérôl és az államadósság várható alakulásáról. Emellett véleményt nyilváníthat a központi költségvetésrôl szóló törvényjavaslatban foglaltak megalapozásához szükséges törvénymódosításokat tartalmazó törvényjavaslatokról, ideértve a közterheket megállapító törvényjavaslatokat is; illetve a központi költségvetés tervezésével, végrehajtásával, a közpénzek egyéb módon történő felhasználásával kapcsolatos bármely kérdésről. A Tanácsnak ez a széles körú véleményezési feladata egyúttal kiterjeszti az ÁSZ elemzési témaköreit is, hiszen az ÁSZ - a hivatkozott törvényi rendelkezés értelmében - elemzésekkel és tanulmányokkal segíti a Tanácsot feladatai ellátásában. 
Fontos megjegyezni, hogy az ÁSZ elemzései elsôsorban saját ellenôrzési megállapításain alapulnak, bár természetesen statisztikai adatokat és szakirodalmi megállapításokat is feldolgoznak. Kiemelendô, hogy a Tanács részére készülô, a költségvetési véleményezést segítô elemzések szinte teljes mértékben az ÁSZ ellenôrzése során összegyújtött és feldolgozott ellenôrzési bizonyítékokon alapulnak, tehát megbízhatóbbak bármely statisztikai adatszolgáltatásnál vagy tudományos becslésnél. Az ÁSZ költségvetési törvényjavaslatra vonatkozó saját véleményét korábban is ellenôrzéssel alapozta meg. A költségvetési tanácsi funkciója teljesítése érdekében a költségvetés véleményezését megalapozó ellenôrzését két irányban is meghosszabbította, azaz hamarabb kezdi, és késôbb fejezi be. A korábbi kezdés révén ellenôrzési bizonyítékokat gyújt a költségvetési törvényjavaslat tervezetének elemzéséhez. A későbbi befejezés révén pedig elsôsorban azt ellenôrzi, hogy az államháztartásért felelôs minisztérium kellő számításokkal, hatástanulmányokkal alátámasztotta-e azokat a döntéseket, amikor a kormány nevében módosító indítványokat támogatott. Az ellenôrzés révén az ÁSZ arról is meggyôzoôdhet, hogy a módosító indítványok végrehajtásának (pl. egy, a gazdaság kifehérítését szolgáló informatikai fejlesztésnek) megvannak-e a feltételei. A Tanács csak a tények feltárása alapján tud megalapozottan állást foglalni abban, hogy a hiány nem haladja-e majd meg az államadósság-szabály teljesítéséhez szükséges mértéket. A vétó szempontjából az előirányzatok realitása az alapvetô kérdés, hiszen az nyilvánvaló, hogy a megszavazásra váró törvényjavaslat számai formálisan minden esetben eleget tesznek az államadósság-szabályból fakadó követelményeknek.

Az ÁSZ-nak ez az új szerepe azért is fontos a jól irányított állam szempontjából, mert az ÁSZ folyamatosan végez olyan ellenôrzéseket, amelyek kapcsolódnak a központi költségvetés egyes elóirányzataihoz. Például a Nemzeti Adó- és Vámhivatal ellenôrzése az adóbevételi irányzatok, az Államadósság-kezelô Központ ellenôrzése az adósságkezelési elôirányzatai kapcsán juttatják az ÁSZ-t a költségvetés véleményezése szempontjából is lényeges információkhoz. Ezek az információk pedig rendre beépülnek azokba az elemzésekbe, amelyeket az ÁSZ a Tanács munkájának segítése céljából készít, és amelyeket megküld az illetékes állami szervek vezetôinek is.

\section{KÖVETKEZTETÉSEK}

A 2008-2009-es pénzügyi, gazdasági válság megrendítette a jóléti állam alapelvárásaiban neoliberális gazdaságpolitikát folytató országok fenntartható múködését. Az addig inkább passzív felügyelô, „éjjeliőr állam” felfogása helyett az állam aktív, válságkezelő, fenntartható fejlődést biztosító szerepvállalása került a kormányzati cselekvés előterébe. A paradigmaváltást állami akciótervek sora jellemezte. A monetáris politika területén tapasztalható, egyre erôsödô jegybanki intervenciót a fiskális politika eszköztárába tartozó intézkedések követték, például a pénzügyi közvetítőrendszer és a nagyszámú munkavállalót foglalkoztató vállalatok, illetve az eladósodott lakosság pénzügyi helyzetének konszolidációját támogató, széles körú reorganizációs programok.

Az állam aktívabb szerepvállalása a legfőbb ellenőrző szervezetek tevékenységére is jelentős hatást gyakorolt. Az „ôrző” típusú szervezetekkel szemben egyre gyakrabban 
Domokos László: Miként támogatja az Állami Számvevốszék a jó kormányzást...

fogalmazódott meg az a közéleti elvárás, hogy egyfajta „terelő”, iránymutató szerepet is betöltsenek. Ezzel párhuzamosan az ellenôrzési tevékenység fokozása, az ellenôrzések által lefedett idôszak és terület kiszélesítése iránt is megnőtt az igény. Az alaptípusnak tekinthetố utólagos ellenôrzés mellett megjelentek tehát az elôzetesen végzett, ex ante típusú tevékenységek, amelyek a számvevôszék elemzési, valamint tanácsadási funkcióiban, kockázatelemzésekben, megalapozó tanulmányokban öltöttek testet.

Az aktív állam a legfóbb ellenôrzô szervet is cselekvésre ösztönzi, arra, hogy a jó kormányzás támogatása érdekében vállaljon a korábbinál nagyobb szerepet, tevékenységén, funkciói kiszélesítésén keresztül járuljon hozzá a jóléti állam fenntarthatóságának megteremtéséhez, ezáltal az állampolgárok életének, biztonságának javulásához. A számvevôszék váljon modellintézménnyé, és így példaszerú múködésével ösztönözze a közszféra más intézményeinek átalakulását is. Összefoglalóan: az aktív állam aktív számvevôszéket igényel.

\section{FELHASZNÁLT IRODALOM}

ÁSZ (2012a): Összegzés a helyi önkormányzatok pénzügyi helyzetének és gazdálkodási rendszerének 2011. évi ellenốrzéseirôl. 1282. sz., Állami Számvevôszék.

ÁSZ (2012b): Jelentés az államháztartás központi alrendszerének adóssága és éven túli kötelezettségvállalásának ellenôrzésérôl. 1294. sz., Állami Számvevôszék.

ÁSZ (2014): Módszertani útmutató a Magyarország központi költségvetésérôl szóló törvényjavaslat véleményezését megalapozó ellenốrzéshez. (Valamint a 2015. és 2016. évi ellenôrzésre vonatkozó kiegészítések.) Állami Számvevôszék, https://asz.hu/hu/egyeb-utmutatok.

Domokos László - Pulay Gyula - Petô Krisztina - Pongrácz Éva (2015): Az Állami Számvevôszék szerepe az államháztartás stabilitásának megteremtésében. Pénzügyi Szemle, 60. évf., 4. sz., 427-443.

Domokos László - Németh Erzsébet - Jakovác Katalin (2016): Supporting the Performance And Efficiency of Governance. Expediency Control and Performance Measurement in SAI's Audit. Public Governance Administration and Finance Law Review in the European Union and Central Eastern Europe, Vol. 1, No. 1, $47-64$.

Domokos, László - Holman, Magdolna (2017): The Methodological Renewal of the State Audit Office of Hungary in Light of the Protection of Public Funds. Polgári Szemle / Civic Review, Vol. 13, Special Issue, 83-98, https://doi.org/10.24307/psz.2017.0306.

Lentner, Csaba (2015): Uncertainty Factors in National Economy Planning. International Effects and Hungary's Outlook Up to 2050. Central European Political Science Review, Vol. 16, No. 62, 9-26.

Lentner, Csaba (2017): Scientific Taxonomy of Hungarian Public Finances After 2010. Polgári Szemle / Civic Review, Vol. 13, Special Issue, 21-38, https://doi.org/10.24307/psz.2017.0303.

Pulay Gyula - Máté János - Németh Ildikó - Zelei Andrásné (2013): Milyen kockázatokat hordoz a monetáris politika az államadósság-szabály teljesülésére nézve? Pénzügyi Szemle, 58. évf., 1. sz., 11-34.

Pulay Gyula - Bagoly Brigitta - Gácser József (2015): Tanulmány a versenyképes tudás megszerzését és hasznosítását szolgáló állami intézkedések számvevốszéki ellenôrzése szempontjainak és fókuszterületeinek meghatározásához. Állami Számvevôszék, https:/ /asz.hu/tanulmanyok-2015-ev.

Pulay Gyula - Köllôdné Gátai Mária - Vargha Bálint (2016): Tanulmány az állam piacszervezô tevékenysége számvevốszéki ellenốrzése szempontjainak és fókuszterületeinek meghatározásához. Állami Számvevôszék, https:/ /asz. $\mathrm{hu} / \mathrm{hu} /$ tanulmanyok-2016-ev.

Pulay Gyula - Szilágyi Gábor Antal - Balázs Melinda - Jakab Laura (2017): A magyar kutatás-fejlesztés és innovációs tevékenység eredményessége. Állami Számvevôszék, https://asz.hu/hu/tanulmanyok-2017-ev. 